\title{
Pedoseksualiteit as manifestasie van afwykende seksualiteit: 'n Kerklike en pastorale uitdaging
}

\begin{abstract}
Authors:
Stella D. Potgieter ${ }^{1}$

George A. Lotter ${ }^{1}$

Affiliations:

${ }^{1}$ School of Practical Theology, North-West University,

South Africa

Correspondence to:

Stella Potgieter

Email:

stellapotgieter@gmail.com

Postal address:

William Street, Helen's walk

37, Matjiesbult, Wilkoppies,

Klerksdorp 2571

Dates:

Received: 24 May 2011

Accepted: 15 Aug. 2012

Published: 23 July 2013

How to cite this article:

Potgieter, S.D. \& Lotter, G.A.,

2013, 'Pedoseksualiteit as

manifestasie van afwykende

seksualiteit: 'n Kerklike en

pastorale uitdaging', In die

Skriflig/In Luce Verbi 47(1),

Art. \#646, 9 pages.

http://dx.doi.org/10.4102/

ids.v47i1.646
\end{abstract}

\section{Copyright:}

(C) 2013. The Authors.

Licensee: AOSIS

OpenJournals. This work

is licensed under the

Creative Commons

Attribution License.
Read online:

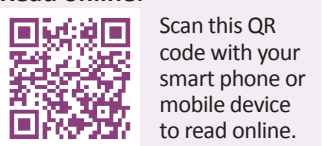

Die fokus van hierdie artikel is om aan te toon dat pedoseksualiteit en pedofilie 'n uitdaging aan die pastoraat en die kerk stel. Nie net in Suid-Afrika nie, maar ook internasionaal is pedoseksuele gedrag ' $n$ wydverspreide probleem. Navorsing op hierdie gebied is ' $n$ pastorale uitdaging. Volgens baie mense is seksueel-afwykende gedrag nie iets wat in die Christengemeenskap voorkom nie. Dit is egter ver van die waarheid af. Pedoseksualiteit en pedofilie kom voor in alle beroepe, op alle sosio-ekonomiese vlakke, in alle ouderdomme, kulture en seksuele oriëntasies en in alle gelowe. Pedofilie word in twee hoofgroepe verdeel, naamlik die situasionele kindermolesteerder en die voorkeur-kindermolesteerder. Die wortels van pedofilie lê normaalweg in die kinderjare terwyl die seksuele wanorde gedurende adolessensie ontwikkel. Drie tipes lewenservaring op 'n vroeë ouderdom word aangedui as aanleidend tot pedoseksualiteit, naamlik seksuele kontak vóór die ouderdom van 16 jaar met 'n aansienlik ouer persoon; seksuele kontak voor die ouderdom van 13 jaar met lede van die eie portuurgroep; en nie-seksuele geweld wat hoofsaaklik deur ouers teenoor kinders gepleeg is. Aangesien daar geen rehabiliteringsprogramme in Suid-Afrika bestaan vir persone met seksueel-afwykende gedrag nie en seksuele waardes vinnig in die breë samelewing afgeneem het, behoort die kerk op die voorgrond te tree op hierdie gebied.

Paedosexuality as manifestation of deviant sexuality: A clerical and pastoral challenge. The focus of this article is to show that paedosexuality and paedophilia poses a challenge to both the pastorate and the church. Not only in South Africa, but also internationally, has paedosexual behaviour become a widespread problem. Research in this field poses a pastoral challenge. According to the opinion of most people sexually deviant behaviour is not something that occurs in the Christian community. This assumption, however, is not the truth. Paedosexuality and paedophilia are present in all occupations, on every socio-economic level, in all age groups, all cultures, in all sexual orientations and religions. Paedophilia can be divided into two main groupings, namely the situational and the preference child molester. The roots of paedophilia can usually be traced back to childhood and the dishevelment developed during adolescence. Three types of life experiences are indicated as causal factors in paedosexuality, namely sexual contact before the age of 16 with someone much older; sexual contact before the age of 13 with members of their peer group; and non-sexual violence committed against them - usually by a parent. The church must take the lead on this matter, as there are no existing rehabilitation programs in South Africa for persons with sexual deviant behaviour while sexual values are waning among the general population.

\section{Inleiding}

Die probleemstelling wat in hierdie artikel ondersoek word, is in 'n relatief nuwe veld van die Praktiese Teologie soos dit betrekking het op pedoseksualiteit. Seksualiteit is deel van die menslike wese, maar wanneer dit in pedoseksualiteit of pedofilie ontaard, word almal wat daarmee in aanraking kom, in hulle totaliteit beïnvloed. Die primêre fokus van hierdie artikel is om aan te toon dat pedoseksualiteit en pedofilie ' $n$ uitdaging aan die pastoraat en die kerk bied.

Die weg word ook gebaan waarop die pastoraat meer van hierdie verskynsel bewus kan raak sodat gemeenskappe beskerm kan word. Die terughoudendheid van die pastoraat ten opsigte van debatte aangaande seksualiteit en besonderlik pedoseksualiteit en pedofilie spoor persone met afwykkende seksuele gedrag aan om met die gedrag vol te hou. Hierdeur word hulle sosiaal geïsoleer (Naudé 2005:28). Molestering vind makliker plaas in sodanige situasie (Ivey \& Simpson 1998:15). Landman (1998:17) maan dat dit nie sal help om landswette met morele wette te vervang nie. Sy meen verder ook dat dit nie help om wette te soek wat rigied toegepas word ten opsigte van elke geval nie. Die tyd van moraliste wat vir almal dieselfde morele wette wil voorskryf, is verby. Godsdienstige mense moet die vaardighede aanleer om self situasies te hanteer waarby seks betrokke is. Verskillende situasies het egter uitlopende vaardighede nodig. Hierdie stelling 
sou definitief ook geld ten opsigte van die kerk in kontak met persone wat seksueel-afwykende gedrag openbaar.

Pedoseksualiteit en pedofilie ${ }^{1}$ bied 'n uitdaging aan die pastoraat omdat mense nie maklik daaroor praat nie - selfs professionele persone skram weg van hierdie onderwerp (Hutsebaut 2011:549). Dit is 'n onderwerp wat in die negatiewe sosiale diskoers ingebed is. Nie net in SuidAfrika nie (Hesselink-Louw \& Schoeman 2003:158; Marais 1990:83), maar ook internasionaal, is pedoseksualiteit 'n wydverspreide en toenemende probleem (Bukau 2003:501). In plaas van 'n bron van krag en vreugde, word seksualiteit ' $n$ donker geheim wat die persoon van ware lewensvervulling beroof en soms tot vernietiging lei. Die gevolg is dat hierdie persoon in 'n stryd gewikkel is om te kan onderskei tussen dít wat normaal en gesond is en dít wat siek, sondig en disfunksioneel is.

Pedoseksualiteit en pedofilie is volgens die meerderheid mense nie iets wat in die Christen-gemeenskap voorkom nie. Dit is egter nie die werklikheidsprentjie nie (Draper 1996:28). 'n Studie deur Pryor (1996) bevind dat 52\% van alle pedofiele wat aan die studie deelgeneem het, protestants was, en Van Dam (2001) voer aan dat 60\% van alle molesteerders Christene is. Indien hierdie onderwerp wel in die pastoraat ter sprake kom, val die fokus onmiddellik op die wyse waarop die kind (as slagoffer) benadeel word en hoe straf toegepas moet word. Min oorweging word egter aan die bose kringloop van die proses geskenk. Howitt (1995:34) asook Hall en Hall (2007:458) beweer: 'The roots of paedophilia lie in childhood.' [Die wortels van pedofilie lê in die kindertyd.] Die molesteerder se agtergrondsgeskiedenis wat met molestering gepaard gaan, is gewoonlik eerder die reël as die uitsondering (Potgieter 1997:181; Standford 1988:91; O'Hagan 1993:52; Sweeney 2008:9; Pryor 1996:261). Daar moet egter daarop gewys word dat nie alle slagoffers van seksuele molestering 'n molesteerder word nie (Pryor 1996:261; Powell 2007:9), hoewel so 'n persoon wel 'n risiko is (Gilgun 2009:39, 154). Molesteerders wat nooit self as kind gemolesteer is nie, kom ook wel voor (Van Dam 2001:91).

Onlangse onthullings oor pedoseksuele dade van Katolieke priesters en lede van die godsdiensorde geniet voortdurende aandag (Gouws 2011). Daarom is dit vir die pastoraat van kardinale belang om kennis te neem van pedoseksueelafwykende gedrag.

\section{Die leemte}

Pedoseksualiteit en pedofilie word as 'n kontrasterende seksualiteit teenoor 'n gebalanseerde, bybelgegewe en morele seksualiteit bespreek.

In Suid-Afrika kon baie min navorsing in die pastoraat opgespoor word ten opsigte van pastorale bediening vir pedoseksualiteit. Navorsing op hierdie gebied is dus 'n pastorale uitdaging. Baie navorsing is wel oor die slagoffer

1.Vir die onderskeid tussen pedoseksualiteit en pedofilie, vergelyk 'Pedoseksualiteit en pedofilie' verder in die artikel. gedoen (vgl. Denton 2005; Britz 2003), of oor pedofilie (vgl. Wolfaardt 2003; Naudé 2005).

'n Voëlvlugoorsig word vervolgens gegee oor enkele konsepte wat verband hou met pedoseksualiteit en pedofilie, sodat die erns van die saak verduidelik en besef kan word.

\section{Pedoseksualiteit en pedofilie}

Die terme pedofilie en pedoseksualiteit word gewoonlik verwar (Hutsebaut 2011:23). Pedofilie word onder parafilie geklassifiseer as 'n abnormale uitdrukking van seksualiteit (Kaplan \& Sadock 1998:718; Flora 2001:66). Pedofilie kan beskou word as 'n seksuele ingesteldheid - nie alle pedofiele is pedoseksuele nie, en nie alle pedoseksuele persone is pedofiele nie (Hutsebaut 2011:23).

Pedoseksualiteit en pedofilie dui op liefdesverhoudings met kinders of met jongmense. Dit is duidelik dat daar 'n onderskeiding gemaak kan word. Waar 'n neiging of gesteldheid by volwassenes tot liefdesverkeer met kinders of met jongmense aangetref word, het 'n mens met pedofilie te make; waar dit egter oorgaan tot 'n praktyk van seksuele verkeer, is dit pedoseksualisme (Heyns 1986:168; Hutsebaut 2011:23). Pedoseksuele handelings is ' $n$ misdaad en is moreel onaanvaarbaar (Hutsebaut 2011:23). Pedofilie op sigself is nie ' $n$ kriminele oortreding nie, maar wanneer 'n persoon seksuele aktiwiteite met kinders inisieer, word die wet oortree en is die persoon ' $n$ kriminele oortreder (Lanning 2008:386). Pedofilie is nie 'n kriminologiese term nie, maar wel 'n kliniese toestand van die oortreder (Hall \& Hall 2007:457). In die kriminologie word die terme kindermolesteerder of kinderoortreder gebruik (Hesselink-Louw \& Schoeman 2003:160; Hall \& Hall 2007:457).

Die kliniese definisie is bepaal deur die Diagnostic and Statistical Manual of Mental Disorders (DSM-IV-TR) wat die Amerikaanse Psigiatriese Vereniging in 2000 gepubliseer het. Volgens die DSM-IV-TR (2000:527) is die diagnostiese kriteria vir pedofilie die volgende:

- Herhalende, intense seksuele fantasieë, seksuele drange of gedrag wat seksuele aktiwiteit met 'n prepubertale kind of kinders (gewoonlik ouderdom 13 jaar en jonger) insluit.

- Die persoon reageer op sy seksuele drange, of die seksuele drange en fantasieë veroorsaak klinies beduidende stres of belemmering in interpersoonlike funksionering.

- Die persoon is ten minste 16 jaar oud en ten minste vyf jaar ouer as die kind of kinders.

Opsommend kan dit soos volg gestel word: Pedofiele is manlike of vroulike volwassenes wat voorkeur gee aan seksuelekontakmetkinders van dieselfde, dieteenoorgestelde of albei geslagte, op 'n meestal nie-gewelddadige wyse. Pedofiele ervaar herhaalde, intense seksuele opwekking deur fantasieë en hulle het gedurig drange om met 'n kind onder sestien seksueel te verkeer, met of sonder penetrasie (Potgieter 2009:62). 
Pedoseksualiteit kom voor in alle beroepe, op alle sosioekonomiese vlakke, by alle ouderdomsgroepe (Marais 1990: voorwoord; O'Hagan 1993:49; Flora 2001:3), in alle kulture (Van Dam 2001:82) of seksuele oriëntasies (Sweeney 2008:9) en onder alle gelowe (O’Hagan 1993:49).

Die FBI (Amerikaanse Federal Bureau of Investigation) het oorspronklik 'n klassifikasie van verskillende tipes molesteerders gedoen (Hutsebaut 2011:43), wat later deur ander wetenskappe oorgeneem is (Schultz 2005:21; Naudé 2005:26). Die twee hoofgroepe is die situatiewe kindermolesteerder en die voorkeur-kindermolesteerder. Die situatiewe kindermolesteerder word verder in vier groepe geklassifiseer, naamlik die regressiewe kindermolesteerder, die moreel-onoordeelkundige kindermolesteerder, die geslags-onoordeelkundige kindermolesteerder, en die naïef-ontoereikende kindermolesteerder. Situatiewe kindermolesteerders wend hulle nie eksklusief tot kinders nie. Hulle verkeer ook seksueel met volwassenes (Naudé 2005:26; Pistorius 2005:296; Pryor 1996:91; Schultz 2005:21). Molestering van 'n kind vind gewoonlik plaas as gevolg van seksuele drange wat nie beheer kan word nie, of dit spruit uit nie-seksuele behoeftes soos mag of woede (Lanning 2008:388).

Na voorkeur-kindermolesteerders word meestal as pedofiele verwys. Hierdie persone verkies seksuele kontak met kinders bo volwassenes (Pryor 1996:91; Schultz 2005:21). Hulle het gewoonlik meer as een slagoffer, omdat hulle 'n behoefte aan gedurige en/of herhalende kontak het (Dawes \& Govender 2007:35; Pistorius 2005:297; Kreston 2007:6). Hulle voer aan dat hulle hul hele lewe lank seksueel tot kinders aangetrokke gevoel het en in adolessensie aktief begin molesteer het (Marais 1990:121; Howitt 1995:16; Salter 1995:25; Potgieter 1997:181). Hierdie persone ly aan emosionele inkongruensie, die term wat gebruik word wanneer 'n persoon se emosionele behoeftes gelykgestel word aan die van ' $n$ kind. Hulle het die behoefte om seksueel met kinders te verkeer omdat hulle eie emosionele behoeftes gelykstaande is aan die van ' $n$ kind (Hutsebaut 2011:23).

Soos reeds gemeld, lê die wortels van pedoseksualiteit in die kinderjare (Howitt 1995:34) en die seksuele wanorde ontwikkel gedurende adolessensie (Howitt 1995:16; Salter 1995:25). Individuele seksuele kenmerke ontwikkel tydens puberteit en dit is gedurende hierdie tydperk dat persone bewus word van hulle kapasiteit vir seksuele opwinding (Louw \& Edwards 2005:434). Sommige pedoseksuele persone bevestig dat hulle aangetrokkenheid tot kinders gedurende hulle puberteit of adolessensie beleef het (Marais 1990:121; Howitt 1995:16; Salter 1995:25; Potgieter 1997:181) en dat dit later gemanifesteer het. Seksuele ontwikkeling word deur gebeurtenisse uit die verlede beïnvloed met 'n kognitiewe versteuring wat daarop volg (Flora 2001:143). Pryor (1996:61) voer in sy studie aan dat persone wat tot molestering oorgegaan het, akute probleme soos isolasie, emosionele ongelukkigheid, seksuele probleme, huweliksprobleme, werksprobleme en familieprobleme ervaar het.
Daar is bevind dat drie tipes lewenservarings tydens ' $n$ jong ouderdom algemeen deur pedoseksuele persone gerapporteer word. Dit kon moontlik aanleiding gegee het tot pedoseksualiteit (Pryor 1996:31-59).Die lewenservarings is die volgende:

- seksuele kontak voor die ouderdom van 16 jaar met 'n aansienlike ouer persoon;

- seksuele kontak voor die ouderdom van 13 jaar met lede van die eie portuurgroep; en

- nie-seksuele geweld, wat hoofsaaklik deur die ouers gepleeg is.

Aangesien hierdie artikel wil beklemtoon hoe belangrik dit vir die pastoraat is om betrokke te raak, word hierdie drie lewenservarings kortliks bespreek.

In die eerste geval word verwys na die re-enactment theory [nabootsingsteorie]. Dit beskryf die direkte herhaling van die seksuele ervarings van die pedoseksuele as 'n kind. 'n Raamwerk is dus daar gestel om skade wat hulle jare later teenoor hulle eie slagoffers aanrig, te rasionaliseer (Carney \& Dew 2003:268; Briggs 1995:13). Hierdeur word seks en liefde ook met mekaar verwar (Pryor 1996:34,152). Later, tydens die molestering van hulle eie slagoffers, word gevoel dat hulle slegs liefde aan hulle slagoffers betoon - in ooreenstemming met die manier waarop daar aan hulle liefde as kinders betoon is (Gilgun 2009:21, 29). 'n Pedoseksuele persoon verduidelik soos volg:

Ek het gedink dat ek net my liefde toon, want ek het my molesteerder se liefde ervaar omdat daar niemand anders was wat aan my liefde betoon het nie. (persoonlike mededeling uit outeur se praktyk)

Die pedoseksuele persone erken dus nie die effek wat molestering op hulle gehad het nie, en ook nie die skade wat hulle aan die slagoffers doen nie.

Die meeste pedoseksuele persone het hulle eerste seksuele ondervinding tussen die ouderdom van sewe en twaalf jaar gehad (Howitt 1995:26). 'n Ondervinding dui egter op kennis wat opgedoen word deur iets te doen. Volgens Howitt (1995:175) is dit die mate van betrokkenheid by nietraumatiese seksuele ervarings en portuurgroepseks, wat vroeë seksualisering bepaal. Navorsing toon verder dat vroeë seksualisering 'n sterk invloed op die seksuele fantasieë en gedrag van pedoseksuele persone het (Pryor 1996:44).

'n Derde tipe lewenservaring op 'n jong ouderdom wat by pedoseksuele persone geïdentifiseer is, is nie-seksuele geweld wat deur ouers gepleeg is (Pryor 1996:159; Gilgun 2009:21). Hierdie persone was aan jare se emosionele pyn, intimidasie en fisiese geweld onderworpe. Studies onder pedoseksuele mans toon onder andere dat die verhouding met hulle moeders problematies was (Wolfaardt 2003:116; Howitt 1995:34).

Een van die algemeenste psigiese kwaliteite van pedoseksuele persone is emosionele onvolwassenheid (Gilgun 2009:30). Hulle is nie in kontak met hulle eie gevoelens nie en het 
ook swak beheer daaroor (Hall \& Hall 2007:462; Van Dam 2001:71; Potgieter 1997:181-185). Dit is vir hulle makliker om seksuele grense met kinders te oorskry, want hulle is grootliks van hulle emosies afgesny of afgestomp (Pryor 1996:59; Hutsebaut 2011:1949).

Kognitiewe verdraaiing vind ook plaas. Hulle minimaliseer, rasionaliseer (regverdig) of ontken gewoonlik hulle dade (Briggs 1995:13; Carney \& Dew 2003:268; Pryor 1996:174182).

Die volgende kognitiewe distorsies is kenmerkend van pedoseksualiteit (Abel et al. 1987:16):

- 'n Kind wat nie weerstand bied nie, wil werklik seks hê.

- Om seksueel met kinders te verkeer, is 'n goeie manier van seksuele opvoeding.

- Die kind wat seksuele aktiwiteite geheim hou, doen dit omdat hyof sy dit geniet.

- 'n Volwassene, wat slegs 'n kind se genitalieë streel, het nie werklik seks met die kind nie, en daar word geen skade aan die kind aangerig nie.

- Die pedoseksuele persoon gee slegs liefde aan die kind.

In die lig van hierdie kort verduideliking kan tot die gevolgtrekking gekom word dat pedoseksualiteit 'n abnormale uitdrukking van seksualiteit is.

In die volgende afdeling volg ' $n$ kort verduideliking van wat met die pastoraat bedoel word.

\section{Die pastoraat}

Die pastoraat wil lewensvraagstukke sinvol vanuit 'n Christelike geloofsbeskouing ondersoek, aan mense hulp verleen en hoop bied vanuit die oortuiging dat God se trou die inhoud van die geloof is en dat God sy beloftes aangaande die heil van die mens in Christus se kruis en opstanding vervul het (die eskatologiese perspektief). Die pastoraat handel verder met die oortuiging dat lewe in die teenwoordigheid van God voltrek word (Louw 1999:2). Die pastoraat poog om God se wil in terme van die vraag na die sin van die lewe, asook die teenoorgestelde, te vertolk sodat mense met vreugde en hoop kan leef. Navorsing het bewys dat die pedoseksuele persoon ' $n$ intense Godsverwydering en 'n sinneloosheid van die lewe beleef (Potgieter 2009).

Alhoewel hierdie artikel op die pastoraat met betrekking tot pedoseksualiteit fokus, lê dit buite die ondersoekveld om 'n uitgebreide uiteensetting van die Christelike seksuele etiek te gee (Potgieter 2009). Christelike seksualiteit kan die onderwerp vir 'n volgende navorsingsgeleentheid wees.

Die pastoraat word tradisioneel as die versorgingsaksie van die kerk aan gelowiges gesien (Van Wyk 2007:2). Hier vind dus ' $n$ ontmoetingsgebeurtenis plaas. Hierdie ontmoeting tussen God en die mens het verskillende doelwitte. Eerstens help dit persone met afwykende seksualiteit om die Woord se impak in hulle lewens te vertolk (kerugma). Tweedens skep die ontmoeting gemeenskap tussen mense (koinonia) en derdens spoor dit gelowiges aan tot diens in die wêreld (diakonia \& marturia). In die pastorale ontmoeting gaan dit ten diepste daaroor om die betekenis van ons menslike situasie te deurdink en te verstaan in terme van die geloofstaal dat God hier is en dat ek op Hom kan vertrou. Met pastorale begeleiding aan die pedoseksuele persoon en die pedofiel, sou daar 'n ontmoetingsgebeurtenis kon plaasvind. Soos dit ook deur die navorsing (Potgieter 2009) bewys is, het twee persone wat onder hierdie afwykende gedrag gelei het, in diens van die gemeenskap en die gemeentes getree. Hulle spoor persone met dieselfde afwykende gedrag aan om na vore te tree om daardeur ook heling by slagoffers te bewerkstellig.

In die pastoraat is daar omvattende en gesaghebbende gidse gepubliseer, onder andere Daniël Louw se Cura vitae (2008), wat teologies-terapeutiese modelle vir pastorale betrokkenheid by siekte en lyding verduidelik. Verder kies Louw 'n vyf-fase beradingsmodel wat rekening hou met die fases waardeur MIV-positiewe mense gaan. Homoseksualiteit word deeglik bespreek, maar in hierdie verbeeldingryke publikasie word niks van pedoseksualiteit vermeld wat die mens in sy totaliteit kan beïnvloed nie. Dit is van kardinale belang dat die pastoraat hom ook op hierdie afwykende gedragsmanifestering moet toespits.

Coetzer (2005) vra tot watter mate pastorale begeleiding 'n terapeutiese rol kan speel in die helingsproses van die seksueel verslaafde wat binne 'n huweliksverhouding staan. Hiermee gee hy aandag aan die relatief nuwe ondersoekveld met betrekking tot seksuele verslawing. Hy wys daarop dat seksualiteit deel is van die mens se wese, maar wanneer dit in kompulsiewe gedrag ontaard, kan dit die betrokke persoon totaal ontwortel en vernietig. Omdat seksuele verslawing een van die boublokke van pedoseksualiteit is, is die bestudering van seksuele verslawing 'n aktuele saak.

Hoe meer die pastoraat in die praktyk betrokke is, hoe meer word die pastoraat aan die hele empiriese veld van navorsing op die gebied van hulpverlening blootgestel (Louw 1999:4). Omdat die pastoraat ' $n$ hermeneutiese aangeleentheid is, sou die ervaringswêreld van 'n persoon wat kinders molesteer uiteindelik hulp of herstel van die gemeenskap beteken.

\section{Die kerk en pastorale betrokkenheid}

Volgens die Bybel is die kerk die liggaam van Christus - dus van almal wat hulle geloof in Jesus Christus geplaas het vir hulle redding en saligmaking (Joh 3:16; Kor 12:13). Wanneer in hierdie artikel gepraat word van die kerk moet dit deurgaans as die liggaam van gelowiges beskou word (vlg. 1 Kor 12:12-27 \& Ef 4:11-17) soos dit na vore kom op die plaaslike vlak in die plaaslike gemeenskap. Hierdie gemeenskap het tot 'n wedergeboorte in Jesus Christus gekom en is nie bloot 'n aantal mense wat op Sondae bymekaar kom, of wat lidmaatskap van die een of ander kerkdenominasie het nie.

In Suid-Afrika neem misdaad, veral seksuele misdaad, hand oor hand toe (Kempe 2011). Dit is 'n regstreekse uitvloeisel 
van die regering se politieke besluit om die gespesialiseerde eenhede teen gesinsgeweld, seksuele oortredings en kinderbeskerming te ontbind (Kohler-Barnard 2009:21). 'n Nuwe eenheid het op 01 Junie 2010 die lig gesien, naamlik die Gesinsgeweld, Kinderbeskerming en Seksuele Misdrywe Eenheid (GKS) wat hierdie misdaad help bekamp.

Daar bestaan tans geen amptelike rehabilitasieprogram vir seksuele pedoseksuele persone in die Departement Korrektiewe Dienste nie (Van der Westhuizen 2005:118). In 'n resente soektog op die internet (soekterme: rehabilitasie, seksueel afwykende gedrag, pedofilie) is geen sodanige programme of sentrums in Suid-Afrika gevind nie. Die soektog is ook in Engels gedoen. Indien daar wel sodanige program geskep sou word, sou die uitvoering daarvan ten volle aan die oordeel van die terapeut oorgelaat wees. Persone wat in 'n psigologiese en maatskaplike hoedanigheid binne die Korrektiewe Dienste optree, is vrywilligers. Programme vir pedoseksualiteit word meestal deur maatskaplike werkers met 'n belangstelling in hierdie gebied saamgestel en word op die ontwikkeling van verhoudings en lewensvaardighede gebaseer en nie noodwendig op hulle seksueel-afwykende gedrag nie (Hesselink-Louw \& Schoeman 2003:162). Maatskaplike werkers voel soms onseker wanneer hulle met die probleem van seksuele misbruik te make het. Een rede hiervoor is dat daar weinig tyd aan seksuele misbruik as ' $n$ onderwerp gedurende hulle voorgraadse opleiding afgestaan word. Gevolglik is die maatskaplike werker se kennisbasis oor seksuele misbruik en die behandeling daarvan beperk (Spies 1991:95). 'n Opname (Britz 2003:192) wat tydens die Handle them with Care Conference (1999) onder 52 praktiserende maatskaplike werkers en sielkundiges gemaak is, het aangedui dat $89 \%$ van die professionele persone minder as vyf lesings oor seksuele misbruik tydens hulle opleiding gehad het. Hutsebaut (2011:819) voer ook aan dat '... many professionals don't even know what to do with this problem and even have a major problem talking about sex' [... baie professionele persone weet nie eers wat om met so 'n probleem te maak nie en het selfs 'n groot probleem om oor seks te praat].

Daar kan dus tot die gevolgtrekking gekom word dat 'n persoon wat kinders molesteer en tronk toe gestuur word, een of ander tyd weer vrygelaat sal word met steeds dieselfde probleem. Die hof vonnis oortreders tot gemeenskapsdiens en hulle moet ook rehabilitasieprogramme voltooi - wat tans nie bestaan nie. In die uitvoering van hierdie navorsing kon geen fasiliteit vir die volwasse oortreder opgespoor word wat ' $n$ rehabiliteringsdiens lewer nie. Vir die kind wat 'n molesteer is, is daar die Teddy Bear-kliniek in Soweto, Krugersdorp en Ikhaya. Hier word slegs op die psigiese benadeling gefokus en geensins op die geestelike letsel wat molestering op ' $n$ kind laat nie. Hutsebaut beveel aan dat daar gespesialiseerde behandeling vir pedoseksuele persone beskikbaar moet wees. 'And we absolutely need the right attitude to address the offender or the potential offender to make him or her aware that he is responsible for his acts.' ['n Mens moet absoluut die regte aanslag hê om met die oortreder of die potensiële oortreder te werk en hulle daarvan bewus te maak dat elkeen self verantwoordelik is vir sy of haar dade.] (Hutsebaut 2011:878).

Allender (2004) meen dat die kerk op hierdie gebied glad nie sy plig nakom nie:

The church has failed to use its historic platform of the pulpit, Sunday school, pastoral epistles and small group Bible studies to address the phenomena of abuse. The battle will not turn until the church as a whole, rather than individual therapists and people helpers name the problem of abuse. [Die kerk het misluk om die historiese platform van die preekstoel, Sondagskool, pastorale briewe en kleingroep-Bybelstudie te gebruik om die fenomeen van mishandeling te hanteer. Die stryd sal nie gewen word voordat die kerk nie as 'n geheel, eerder as deur individuele terapeute en helpers, toetree tot die mishandelingsprobleem nie.] (bl. 1, [outeur se eie vertaling])

Die kerk soos in die geval van die Rooms-Katolieke Kerk, maak sy oë toe en hou dit toe vir hierdie probleem. Dit is die duiwel se strategie om mense van geloof, hoop en liefde te ontneem. Die kerk raai slagoffers byvoorbeeld aan om te vergewe en te vergeet omdat die kerk nie oor bepaalde probleme soos pedoseksualiteit wil praat nie en ook omdat die nodige kennis nie beskikbaar is nie. Op grond van die landswette is die kerk medepligtig vanweë die feit dat daar geswyg word. Indien die kerk vinnige of oppervlakkige kure voorskryf, kan dit tot nog groter verwarring lei by die persoon wat gemolesteer is en veroorsaak dat dieselfde gedrag herhaal word. Allender (2004) sê:

Quick cures never resolve the deep damage. Instead, they offer change that requires little more than lying on a gurney before surgery: be still and let the experts do their work. [Kitsoplossings los nie diep skade op nie. Inteendeel, dit bied ' $n$ verandering aan wat niks meer verg as om op die trollie te lê voor 'n operasie nie: bly stil en laat die deskundiges hulle werk doen.] (bl. 1, [outeur se eie vertaling])

Die kerk se verantwoordelikheid teenoor sy lidmate is pastorale sorg, pastorale berading en pastorale psigoterapie. Sweeney (2008:9) meen dat die verwonding deur seksuele molestering en pedoseksualiteit so ernstig is dat die Christelike gemeenskap en die kerk die voortou behoort te neem om hierdie verskynsel doeltreffend te bestry. Louw (2008:356) meen op sy beurt dat die kerk beskikbaar moet wees vir hierdie lydende mense. Hierdie stellings is myns insiens geregverdig, aangesien dit alleen deur pastorale hulp en die betrokkenheid van die kerk is dat sulke persone gehelp sal kan word om hulle omstandighede vierkantig in die oë te kyk.

Daar is geen groter tekortkoming onder die Christene as die gebrek aan 'n oortuigende standpunt ten opsigte van seksualiteit nie. Buite die kerk beskou die mense God as die groot pretbederwer van menslike seksualiteit en nie as die skepper daarvan nie (Yancey 2004:78). In die seksbehepte samelewing van vandag vind selfs ware gelowiges dit moeilik om te aanvaar dat die tradisionele Christelike moraliteit die volste en mees bevredigende lewe bied. Ondanks die feit dat die Pous verklarings doen en kerke situasieskrifte uitreik, ignoreer baie Christene hierdie standpunte en volg hulle steeds die voorbeeld van die res van die samelewing. 
Die uiteinde is dat daar min verskil is tussen kerkgangers en kerkloses ten opsigte van voorhuwelikse seks en saamwonery. Dit is ook kommerwekkend dat miljoene mense die kerk verlaat het uit weersin teen die skynheiligheid oor seks, veral wanneer priesters en predikante se dade nie met hulle woorde ooreenstem nie.

Die pedoseksuele persoon het ' $n$ wanbegrip, wanoortuiging en 'n disfunksionele seksualiteit. Indien die kerk nie 'n poging aanwend om seksualiteit te herskep soos God dit oorspronklik vir die mens beplan het nie, of op hierdie gebied betrokke raak nie, sal die bose kringloop net voortgaan.

Dit is baie belangrik dat leraars deeglike kennis sal dra van die problematiek rondom pedoseksualiteit. Dit is menige keer leraars wat eerste by krisisgevalle betrek word. In baie gevalle word pedoseksuele persone verwys omdat leraars ongemaklik voel om oor seksualiteit te praat, of nie bereid is om te erken dat hulle nie die nodige kennis oor die onderwerp het nie.

Dit is nogal ironies dat die kerk dikwels die laaste plek is waar mense met vryheid en openheid oor die aangeleenthede wat hulle die diepste raak, kan praat (Clinebell 1984:351352). Pedofiele is eerder bereid om met hierdie diep donker geheim saam te leef en aan te hou molesteer, as om vir hulp aan te klop. Predikers skep dikwels by mense die verkeerde idee, naamlik dat die nuwe geboorte en 'vervulling met die Gees' outomaties alle probleme sal genees. Dit is eenvoudig nie waar nie. Persone met seksueel-afwykende gedrag is deeglik daarvan bewus dat die kerk nie vir sy taak oor hierdie onderwerp ingelig is nie, en daarom verkies hulle om eerder te swyg.

Hoop is iets wat in die Christelike kerk tuishoort. Hoop bind gelowiges saam en hoop wat met ander gedeel word, is 'n belewenis. ' $n$ Kerk met hoop het ' $n$ visie vir die toekoms. Hoop versterk verhoudings tussen mense, want hoop is vertroue en 'n strewe na intimiteit en liefde. Daarom is hoop nie 'n private saak nie (Lester 1995:96). Hoop is dit wat die persoon met seksueel-afwykende gedrag nodig het. Persone wat seksueel-afwykende gedrag openbaar, is dikwels mense waarvan niemand dit verwag nie. Dit is persone wat tussen ons leef. Indien die kerk hoop aan hierdie persone kan bied, sal daar ook hoop by hulle wees om beheer van die probleem te kan neem en dit te kan bestuur.

Pedoseksuele persone word as uitgeworpenes beskou met wie die samelewing en die kerk niks te doen wil hê nie. God het sy gemarginaliseerde volk se smeekroep in Egipte gehoor. Die God van die Ou Testament het ook versoek dat daar plek aan vreemdelinge gegee moet word (Eks 22:21). Armes mag nie uitgebuit word en nie-volksgenote mag nie vertrap word nie.

In die gelykenis van die groot maaltyd (Luk 14:15-24) word God uitgebeeld as die Een wat omgee en deernis het met die gemarginaliseerdes van Jesus se tyd - armes, kreupeles, blindes en verlamdes word na die maaltyd genooi. Jesus vereenselwig Hom met die nood van die uitgeworpenes. Hy sê dat wie aan hulle reg en goed doen, dit ook aan Hom doen.

Die kerk weet nie hóé om hierdie gemarginaliseerdes (persone met afwykende seksuele gedrag) by te staan nie, omdat kennis ontbreek. Die vraag is of hierdie probleem as 'n sosiale probleem beskou kan word wat nie deur die kerk aangepak moet word nie. Leraars voel ongemaklik om oor hierdie afwyking te praat. 'n Voorbeeld vanuit die navorser se pastorale spreekkamer is onder andere die volgende: Billy ${ }^{2}$ was 'n ouderling in die kerk en hy het talle kere probeer om by sy leraar hulp vir sy seksuele afwykende gedrag te vind. Die leraar het egter aanbeveel dat hy homself tot gebed moet wend wanneer afwykende gedagtes by hom opkom. Billy het dit probeer, maar is uiteindelik gevang en het tronkstraf uitgedien.

In sy boek, Healing for damaged emotions, haal Seamands (2002) 'n pastoor, aan:

You know, there was always a group of people I could never help. They were sincere people. I believe many of them were Spirit-filled Christians. But they had problems. They brought these things to me, and I tried to help. But no amount of advice, no amount of Scripture - of prayer on their part - ever seemed to bring them lasting deliverance. [Jy weet, daar was altyd 'n groep mense wat ek nooit kon help nie. Hulle was opregte mense. Ek glo baie van hulle was geesvervulde Christene. Maar hulle het probleme gehad. Hulle het daarmee na my toe gekom en ek het probeer help. Geen advies of skriftuurlike hulp - of gebed van hulle kant af - het egter ooit geblyk om vir hulle durende verligting te bring nie.] (bl. 10, [outeur se eie vertaling])

Hierdie groep mense is persone met seksueel-afwykende gedrag.

Die pedoseksuele persoon wie se verhaal met dié van God gekruis het, wat ' $n$ verhaal van hoop kon bring aan ander wat met dieselfde seksuele afwyking worstel maar wat aanhou molesteer, word egter nie toegelaat om te rehabiliteer nie. Omdat ons glo dat sulke persone nie genees kan word nie, word hulle afgeskryf as deel van die uitgeworpenes van die samelewing en die gemeente. Hierdie mense, wie se verhale, omstandighede of pedofilie hulle daarvan beroof om 'n vervulde verhaal te leef, wat dit wil waag om teen hierdie oorweldigende probleem op te staan, word nie die kans gegun nie. Daar is egter persone wat beheer en bestuur oor hulle seksualiteit aangeleer het en wat in gemeenskappe en gemeentes betrokke is om hierdie probleem te help bekamp (Potgieter 2009; Liautaud 2010:69).

Uit bostaande kan afgelei word dat die kerk 'n besliste rol te speel het in die ondersteuning, begeleiding en bemagtiging van pedoseksuele persone. Vandag se slagoffer kan immers môre se oortreder wees.

\section{Gevolgtrekking}

Pedoseksualiteit is 'n algemene verskynsel. Daar kan geen tipiese persoonlikheidseienskappe geheg word aan die 2.'n Fiktiewe naam. 
persoon wat kinders molesteer nie., In Suid-Afrika is manlike pedofiele egter ver in die meerderheid (95\%) (Kreston 2007:2; Van Dam 2001:75). Een uit elke vier persone wat as kind gemolesteer is, toon dieselfde gedrag as volwassenes. Christene is nie gevrywaar van pedoseksualiteit nie. Die pastoraat en die kerk het 'n verantwoordelikheid om persone wat as kind gemolesteer is en wat ' $n$ disfunksionele seksualiteit toon, by te staan deur begeleiding en bemagtiging vanuit 'n pastorale benadering. Dit behoort 'n uitdaging vir die kerk te wees.

\section{Aanbevelings}

Die kerk het inderdaad 'n baie spesifieke rol te speel ten opsigte van hulpverlening aan gemolesteerde persone. Die kerk kan nie beweer dat molestering nie 'n probleem onder gelowiges is nie, aangesien dit nie klop met wat in die praktyk gebeur nie. Navorsing toon aan dat daar vir elke 100 lidmate in 'n gemeente meer as 30 vroue en omtrent 15 mans is wat vóór die ouderdom van 18 jaar gemolesteer is (Grobler 2005:122). Die vraag is wat van hulle molesteerders geword het. Hoeveel ander persone is nie deur hulle gemolesteer nie? Kon die kerk moontlik ' $n$ rol in hierdie persone se lewens gespeel het?

Clinebell (1984:19) waarsku teen predikante wat die onderlinge versorging tot die studeerkamer beperk. Aanbiedings moet in die gemeentes gehou word om hierdie probleem aan gemeentelede bekend te stel. Persone wat met 'n destruktiewe seksuele afwyking worstel, moet deur die kerk en die groter samelewing ondersteun word.

One fears that one day they will take revenge by making new victims. These hellish circles that come back again and again have to be broken. We have to realize the consequences and take responsibility to protect children, so they won't become balls of hate and anger and they will not become offenders and make new victims in the next generations. [' $n$ Mens vrees dat hulle eendag wraak sal neem en nuwe slagoffers sal maak. Hierdie bose kringloop moet gebreek word. Ons moet die gevolge besef en verantwoordelikheid neem om kinders te beskerm sodat hulle nie speelballe van haat en woede word nie en nie ook oortreders word en nuwe slagoffers in die volgende generasies maak nie.] (Hutsebaut 2011:247, [outeur se eie vertaling])

Omdat seksuele waardes en norme vinniger afplat, sal kinders bewus gemaak moet word van faktore wat aanleiding gee tot ontwrigte seksualiteit, onder andere seksuele kontak met 'n ouer persoon voor die ouderdom van 16 jaar, asook seksuele kontak voor die ouderdom van 13 jaar met lede van hulle eie portuurgroep. Ouers sal daarop gewys moet word dat nieseksuele geweld, wat hoofsaaklik deur hulle gepleeg word, ook pedoseksualiteit tot gevolg kan hê.

Die kerk sal op die voorkomingsvlak betrokke moet raak, omdat dit uiteindelik verreikende gevolge vir die samelewing inhou. Predikers sal die erns van hierdie saak moet besef en gespesialiseerde kennis moet inwin. Morele waardes sal deur die kerk hanteer moet word en as 'n dringende saak in die prediking beklemtoon word. Ouers sal die nodige leiding gebied moet word om kinders te begelei. Onderrig op eksegetiese vlak is van kardinale belang. Hutsebaut
(2011:858, 876) stel: 'It is up to society to help and protect children.' [Dit is die taak van die gemeenskap om kinders te help en te beskerm.] Hy sê verder: 'We cannot expect a child to be responsible for its own safety.' [Ons kan nie verwag dat 'n kind vir sy eie veiligheid verantwoordelik moet wees nie.]

Vergifnis, soos algemeen deur die kerk voorgeskryf word, is nie ál metode wat tot heling lei nie. Pastorale bediening sal aan sulke persone gebied moet word om hulle seksualiteit te herskep. Onderrig aan die liggaam van Christus ten opsigte van seksueel-afwykende gedrag is van kardinale belang in hierdie postmoderne tyd en toerusting sal daarvoor voorsien moet word.

Die vraag is wat die kerk en gelowiges kan doen om die spiraal van kindermolestering te keer en mee te werk aan verhoudings waar respek, vertroue, eerlikheid en verantwoordelikheid bevorder word. Wat kan gedoen word sodat mense nie bang is ander doen hulle kwaad aan nie, of self later kwaad aan ander doen nie?

- Die kerk moet sy medeverantwoordelikheid vir die omvang van hierdie verskynsel erken en aanvaar. Seksuele molestering is nie net die taak van die kriminoloog, die sielkundige of die psigiater nie. Die geestelike dimensie van hierdie seksueel-afwykende persoon word in totaliteit beïnvloed.

- Die kerk moet kinders met al die nodige hulpmiddels en ondersteuning bystaan, sodat hulle bemagtig word om uit die bose kringloop van molestering los te breek. Volgens 'n kongres wat op 3-4 Maart 2011 gehou is (Children who abuse children sexually), is die oortreders in $50 \%$ van die aanmeldings kinders.

- Die kerk moet mans wat in hierdie bose kringloop vasgevang is, ondersteun om verantwoordelikheid vir hulle optrede te aanvaar. 'n Herhaling van seksuele molestering kan voorkom word indien die kerk ondersteuning en behandeling bied en ook in toesighoudende kapasiteit kan optree (Liautaud 2010:69).

- Die kerk moet op hoogte van navorsing oor manlike seksualiteit bly. Hart (1994:37) noem dat manlike seksualiteit hoogs gekompliseerd is.

- Die kerk moet by die gemeenskap betrokke raak, sodat die liggaam van Christus ook in die sekulêre wêreld sigbaar word.

- Die kerk het die groot verantwoordelikheid om aan 'n etiese samelewing mee te werk wat daarna streef om die bose kringloop van molestering te keer - 'n samelewing waarin mense nie bang is nie. Deur 'n ingeligte gemeenskap te wees, kan seksuele molestering beperk word.

- Die kerk kan ook 'n groot rol speel in die herstelproses tussen die oortreder, die slagoffer, die gesin en die gemeenskap.

- Christelike kerke in Suid-Afrika het ' $n$ besondere taak en verantwoordelikheid om mense in ' $n$ ware verhouding met God se aktiewe diakonaat en tekens van die koninkryk te plaas. Die kerk het 'n verantwoordelikheid ten opsigte van die genesing van die noodlydende 
persoon wat ondoeltreffend lewe, sodat hierdie persoon in volheid, produktief, vrugbaar en blymoedig kan lewe (Crabb 1977:191). Elke lidmaat van die kerk moet die geleentheid hê om 'n warm, koesterende gevoel van behorendheid te ervaar.

Laastens kan Hutsebaut (2011) aangehaal word:

We need an enormous amount of courage and good will to put an end to this 'explosive' situation. We need specialized treatment for the offenders as well as for the victims. And we absolutely need the right attitude to address the offender or potential offender to make him or her aware that he is responsible for his acts. Not the child. [Ons het ' $n$ enorme hoeveelheid moed en goeie bedoelings nodig om ' $n$ einde te maak aan hierdie 'plofbare' situasie. Ons het gespesialiseerde behandeling nodig vir die oortreders sowel as vir die slagoffers. By dit alles benodig ons ook die regte ingesteldheid om die oortreders of potensiële oortreders te benader om hulle bewus te maak dat hulle self die verantwoordelikhied moet aanvaar vir hulle eie dade. Nie die kind nie.] (bl. 29, [outeur se eie vertaling])

Alhoewel die kerk nie volledige verantwoordelikhied vir persone met seksueel-afwykende gedrag kan aanvaar nie, kan van die kerk verwag word om ondersteuning, deernis, begeleiding en bemoediging vanuit 'n kerklik-pastorale benadering te bied. Dit impliseer 'n uitdaging aan die kerk, sonder om die verantwoordelikheid van die persone met pedoseksuele afwykende gedrag te ontneem en dit op die kerk te projekteer.

\section{Samevatting}

Pedoseksualiteit is ' $\mathrm{n}$ wydverspreide probleem waaroor mense, en veral die Christendom, nie wil praat nie. Daar word debatte oor homoseksualiteit en die saamwoonvraagstuk gevoer, maar pedoseksualiteit bly 'n verbode onderwerp. Hierdie afwykende seksualiteit kom algemeen in die Christendom voor. Pedoseksualiteit is 'n seksuele afwyking, wat nie genees kan word nie, maar slegs beheer en bestuur kan word. Die kerk behoort aan die voorpunt te staan van die daarstelling van 'n rehabilitasieprogram vir mans wat aan seksuele afwykings ly.

Dit is aangetoon dat die kerk op hierdie gebied onkundig is en daarom ook onwillig is om die pastorale pad met hierdie tipe vergrype te loop. Hierdeur word pedoseksuele persone nie die kans gegun om te genees nie en die bose siklus duur voort.

\section{Erkenning \\ Mededingende belange}

Die outeurs verklaar dat hulle geen finansiële of persoonlike verbintenis het met enige party wat hulle nadelig kon beïnloed het in die skryf van hierdie artikel nie.

\section{Literatuurverwysings}

Abel, G.G., Becker, J.V., Mittelman, M.S., Cunningham-Rathner, J., Rouleau, J.L. \& Murphy, W.D., 1987, 'Self-reported sex crimes of non-incarcerated paraphiliacs' [Selfgerapporteerde seksuele vergrype van nie-opgesluite parafiele], Journal of Interpersonal Violence 2(1), 3-25. http://dx.doi.org/10.1177/088626087002001001

Allender, D.B., 2004, 'Are we winning the battle?', viewed 19 May 2010, from http:// www.reconciliationmin.org.
American Psychiatric Association, 2000, Diagnostic and statistical manual of mental disorders. 4th edn. American Psychiatric Association, Washington.

Briggs, F., 1995, From victim to offender: How child sexual abuse victims become offenders, Allen \& Unwin, St Leonard's.

Britz, L., 2003,."n Intervensiemodel vir die middelkinderjare kind wat seksueel misbruik is', DPhil-proefskrif, Departement Sosiale Wetenskappe, Universiteit van Pretoria, Pretoria.

Bukau, S.C., 2003, 'Kinders as slagoffers van seksuele misdade', PhD-proefskrif, Fakulteit Regte, Universiteit van Suid-Afrika, Pretoria.

Carney, M.P. \& Dew, B.J., 2003, 'Online experiences of sexually compulsive men who have sex with men' [Aanlyn ervarings van suksueel-kompulsiewe mans wat seks met mans het], Sex Addiction \& Compulsivity 10, 259-274. http://dx.doi. org/10.1080/713775414

Clinebell, H., 1984, Basic types of pastoral care and counselling resources for the ministry of healing and growth, Abingdon, Nashville.

Coetzer, W., 2005, Pastorale begeleiding van die seksueel vers/aafde: Ongepubliseerde studiegids, Potchefstroom.

Crabb, L.J., 1977, Effective biblical counseling, Zondervan, Nashville.

Dawes, A. \& Govender, A., 2007, 'The use of children in pornography in South Africa: Final report submitted to the anti-child pornography task team, the film and publications board', Conference of the Human Science Reseach Council held in Benoni on 27-28 September.

Denton, R.A., 2005, 'Die adolessent wat mishandel is se verhouding met God: ' $n$ Pastorale gestaltbenadering', MA-verhandeling, Fakulteit Teologie, Universiteit van Suid-Afrika, Pretoria.

Draper, P.L., 1996, Haunted memories: Healing the pain of childhood abuse, Fleming H. Revell, Grand Rapids.

Flora, R., 2001, How to work with sex offenders: A handbook for criminal justice, human service, and mental health professionals, The Haworth Clinical Practice Press, New York.

Gilgun, J.F., 2009, What child sexual abuse means to abusers: In shame, blame, \& sexual abuse, Kindle edn., Jane Gilgun Books, Amazon Digital Services.

Gouws, A., 2011, 'Die krisis rondom seksualiteit in die Rooms-Katolieke Kerk', besigtig 19 Apr. 2011, vanaf http://www.litnet.co.za/cgi-bin/giga.cgi?cmd=cause_dir news_item\&cause_id $=1270 \&$ news_id $=99346 \&$ cat_id $=226$

Grobler, L., 2005, 'Hulpverlening aan die seksueel gemolesteerde kind met behulp van spelterapie - 'n Pastorale studie, BA Hons-skripsie, Departement praktiese Teologie, Potchefstroomkampus, Noordwes-Universiteit, Potchefstroom.

Hall, R.C.W. \& Hall, R.C.W., 2007, 'A profile of pedophilia: Definition, characteristics of offenders, recidivism, treatment outcomes, and forensic issues' ['n Profiel van pedofilie: Definisie, karaktereienskappe van die oortreders, terugvalling behandelingsuitkoms en forensiese kwessies], Mayo Clinic Proceedings 82(4), 457-471. http://dx.doi.org/10.4065/82.4.457, PMid:17418075

Hart, A.D., 1994, The Hart report: The landmark study of men and sex in the 90's - The sexual man: Masculinity without guilt, Thomas Nelson, Nashville.

Hesselink-Louw, A.E. \& Schoeman, M., 2003, 'Treatment of incarcerated sex offenders in South Africa: An analytical perspective' [Behandeling van seksoortreders in die tronk in Suid-Afrika: 'n Analitiese perspektief], Acta Criminologica 16(1), 158-173.

Heyns, J.A., 1986, Teologiese etiek: Sosiale etiek, Deel 2, NG Kerkboekhandel, Pretoria. Howitt, D., 1995, Paedophiles and sexual offences against children, Wiley, New York.

Hutsebaut, C., 2011, Child hunters: Requiem of a childkiller, Xlibris Publishing, Dartford.

Ivey, G. \& Simpson, P., 1998, 'The psychological life of paedophiles: A phenomenological study' [Die psigologiese lewe van pedofile: 'n Fenomenologiese studie], South African Journal of Psychology 28(1), 15-20. http://dx.doi. org/10.1177/008124639802800103

Kaplan, H.I. \& Sadock, B.J., 1998, Synopsis of psychiatry: Behavioral sciences/clinical psychiatry, Lippincott Williams \& Wilkins, Baltimore.

Kempe, C., 2011, 'Misdaad in visier'. Volksblad, 12 Sept., besigtig 25 Jan. 2012, vanaf http://m.news24.com/volksblad/NoordKaap/Nuus/Misdaad-in-visier-20110912

Kohler-Barnard, D., 2009, 'Misdaadsyfers skets nie die ware prentjie', Rapport, 27 September, bl. 21.

Kreston, S., 2007, Referaat gelewer by kongres vir aanklaers, Aantekeninge vir aanbieding aan Departement van Justisie.

Landman, C., 1998, 'Moraliteit vandag: Kan die kerk sê wat moreel is? Beeld, 2 June, bl. 17.

Lanning, K.V., 2008, “'Pedophiles”: A behavioral perspective', in R.R. Hazelwood \& A.W. Burgess (eds.), Practical aspects of rape investigation: A multidisciplinary approach pp. 381-407, CRC Press, Boca Raton. http://dx.doi.org/10.1201/9781420065053. sec4

Lester, A.D., 1995, Hope in pastoral care and counseling, John Knox, Lousville.

Liautaud, M.V., 2010, 'Offenders coming to a church near you' [Oortreders besoek 'n kerk naby jou], Leadership 3(4), 69-72.

Louw, D.A. \& Edwards, D.J.A., 2005, Sielkunde -'n inleiding vir studente in Suid-Afrika, Heinemann, Johannesburg.

Louw, D.J., 1999, Pastoraat as vertolking en ontmoeting: Teologiese ontwerp vir 'n basisteorie, antropologie, metode en terapie, Lux Verbi.BM, Wellington.

Louw, D.J., 2008, Cura Vitae: IIIness and the healing of life, Lux Verbi.BM, Wellington. Marais, C., 1990, Children of sorrow: Child sex abuse in South Africa, Ashanti, Rivonia. 
Naudé, J., 2005, 'Reconstructing paedophilia: An analysis of current discourses and the construct of close relationships', MA thesis, Department of Psychology, the construct of close relationships',
University of Stellenbosch, Stellenbosch.

O'Hagan, K., 1993, Emotional and psychological abuse of children, Open University Press, Bucking.

Pistorius, M., 2005, Profiling serial killers and other crimes in South Africa, Penguin Books, Johannesburg.

Potgieter, L.M., 1997, 'Psychological case studies of child molesters', MA thesis, Department of psychology, University of the Free State, Bloemfontein.

Potgieter, S., 2009,"n Pastoraal-hermeneutiese benadering tot pedofilie', PhDproefskrif, Departement Praktiese Teologie, Universiteit van die Vrystaat, Bloemfontein.

Powell, A. 2007, Paedophiles, child abuse and the internet: A practical guide to identification, action and prevention, Radcliffe Publishing, Oxon.

Pryor, D.W., 1996, Unspeakable acts: Why men sexually abuse children, University Press, New York.

Salter, A.C., 1995, Transforming trauma: A guide to understanding and treating adult survivors of child sexual abuse, Sage, New Delhi.

Schultz, P.D., 2005, Not monsters: Analysing the stories of child molesters, Rownam \& Littlefield, Lanham.
Seamands, D.A., 2002, Healing for damaged emotions, Victor ${ }^{\circledR}$ Cook Communications Ministries, Colorado Springs.

Spies, G.M., 1991, 'Die problematiek verbonde aan die maatskaplike hantering van die gemolesteerde kind', Koers 56(1), 93-103. http://dx.doi.org/10.4102/koers. v56i1.734

Standford, P., 1988, Healing victims of sexual abuse, Victory House, Oklahoma City.

Sweeney, D.S., 2008, 'Sexual abuse: Victims \& offenders' [Seksuele mishandeling: Slagoffers en oortreders], News from the ACC in SA (3), 8-9.

Van Dam, C., 2001, Identifying child molesters: Preventing child sexual abuse by recognizing the patterns of the offenders, The Haworth Maltreatment and Trauma Press ${ }^{\circledR}$, New York.

Van der Westhuizen, B.M., 2005, 'Die uitwerking van oorbevolking binne SuidAfrikaanse gevangenisse op die rehabilitasie van oortreders', Ongepubliseerde D Litt et Phil-proefskrif, Kriminologie Departement, Universiteit van Suid-Afrika, D Litt et
Pretoria.

Van Wyk, C., 2007, 'Pastoraat in missionale gemeentes', Kruisgewys 7(4), 1-16.

Wolfaardt, L., 2003, 'Mans wat kinders molesteer: 'n Hipno-ontleding', PhD-proefskrif, Psigologie Departement, Randse Afrikaanse Universiteit, Johannesburg.

Yancey, P., 2004, Gerugte van 'n ander wêreld: Wat op aarde kyk ons mis?, Vertaal deur Louise Venter, Struik Christelike Boeke, Kaapstad. 